\title{
Improving Luminescent Solar Concentrator Efficiency by Mixing Acriflavine and Eosin Y Organic Dyes
}

\author{
Adnan F. Hassan and Huda H. R. Abulkashee \\ Department of Physics, Faculty of Sciences, University of Kufa, Najaf, Iraq
}

\begin{abstract}
In this study, a method was proposed to construct a Luminescent Solar Concentrator (LSC). Two organic dyes (Acriflavine and Eosin Y) were dissolved in ethanol liquid and mixed with the addition of epoxy risen to fabricate eight panels of LSC with two different panel thickness $(0.5,1 \mathrm{~mm})$ and different dyes concentrations $\left(2 \times 10^{-5}, 3 \times 10^{-5}, 6 \times 10^{-5}, 10 \times 10^{-5} \mathrm{~mol} / \mathrm{L}\right)$. The efficiency of silicon solar cell was measured before and after the use of LSC. Experiments showed that the best results were in $2 \times 10^{-5} \mathrm{~mol} / \mathrm{L}$ concentration with thickness $1 \mathrm{~mm}$. Results showed that the efficiency was increased from (8.183-9.922\%).
\end{abstract}

Key words: Luminescent solar concentrator, LSC, acriflavine, eosin Y, organic dyes, efficiency

\section{INTRODUCTION}

Sun is one of the most important sources of energy earth. The energy of sun is mainly in two types which are heat and light (Armaroli and Balzani, 2007). Heat is energy in the form of moving particles. As the particles move faster in a substance, the object becomes warmer. Light is energy in the form of waves. These waves travel through space to Earth and we see them as light (Anonymous, 2018a, b). Several studies have been done on developing methodsto transfer the energy of sun heat and light to electrical energy (Dhakal, 2016; Anonymous, 2018a, b). The photovoltaic solar cells are used to convert the solar energy to electrical energy. Many researches have been done to improve the conversion efficiency of the solar cells ( $\mathrm{Li}$ et al., 2013; Anonymous, 2018a, b). Some researches were focused on developing techniques to form a nano sized porous structure on the surface of silicon photovoltaics by simple wet chemical etching process (Lin et al., 2015; Li et al., 2013). Other researches were focused on constructing and using concentrators on the solar cell (Van et al., 2008; Mohamed and Hassan, 2015). These concentrators are plastic or glass panels contain or coated with luminescent materials or dyes that absorb sunlight and emit light at longer wavelengths. The used dyes can be organic dyes or inorganic dyes (Rowan et al., 2008; Reisfeld, 1983). The organic dyes are organic chemicals made from plants, animals or metallic materials. The organic dyes have high fluoridation and it is available widely and inexpensive if compared with inorganic dyes (Truant et al., 1962). In this research, we propose a method to construct Luminescent Solar Concentrator (LSC) panels using two organic dyes (Acriflavine and Eosin Y) were dissolved in ethanol liquid and mixed with the addition of epoxy risen. Different dye concentrations and different LSC panel thicknesses have (a)
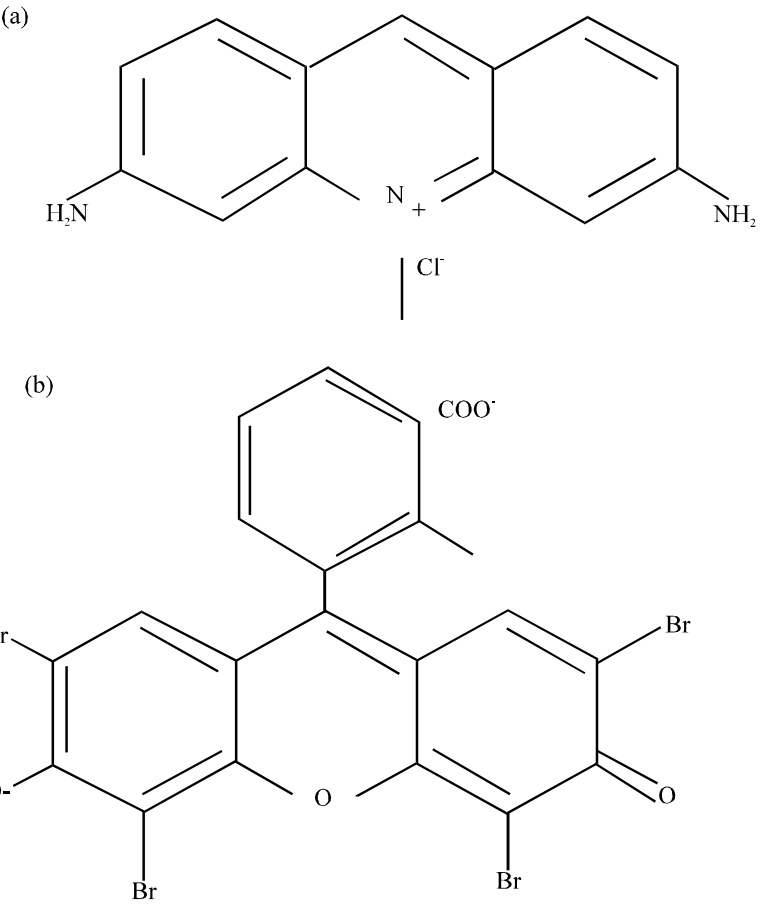

Fig. 1: Chimecal structure of acriflavine and eosin $Y$ organic dyes: a) Acriflavine and b) $\operatorname{cosin} Y$

been used and tested to determine the best concentration and panel thickness which help to increase the conversion efficiency of the solar cell.

\section{MATERIALS AND METHODS}

Acriflavine and eosin $\mathrm{Y}$ organic dyes: Acriflavine is derived from (acridine amily). Figure 1a shows the 
Table 1:Properties of acriflavine and eosin Y organic dyes

\begin{tabular}{lll}
\hline Properties & Acriflavine (Ladoulis and Gill, 1970) & Eosin (Ulrieh et al., 2008) \\
\hline Molecular formula & $\mathrm{C}_{14} \mathrm{H}_{14} \mathrm{CIN}_{3}$ & $\mathrm{C}_{20} \mathrm{H}_{8} \mathrm{Br}_{4} \mathrm{Na}_{2} \mathrm{O}_{5}$ \\
Molar mass & $260 \mathrm{~g} \cdot \mathrm{mol}^{-1}$ & $691.9 \mathrm{~g} . \mathrm{mol}^{-1}$ \\
$\lambda_{\max }$ of absorbance & $450 \mathrm{~nm}$ & $518 \mathrm{~nm}$ \\
$\lambda_{\max }$ of flourescence & $458 \mathrm{~nm}$ & $544 \mathrm{~nm}$ \\
Other names & Acriflavinium chloride & Acid red 87 \\
Form & Powder & Powder \\
\hline
\end{tabular}

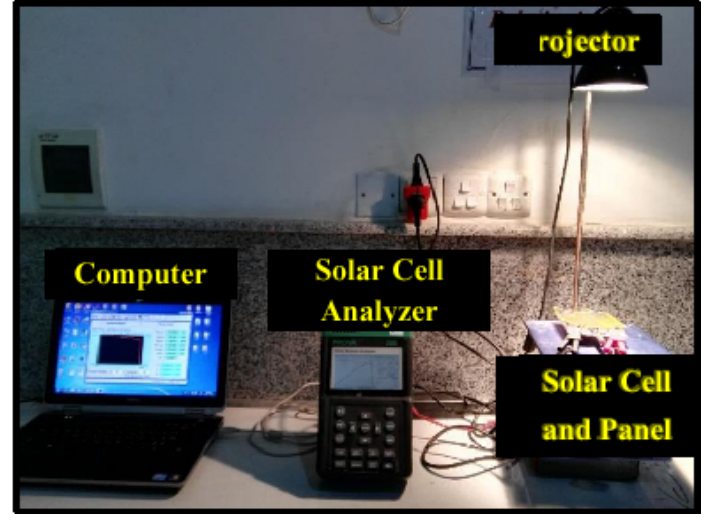

Fig. 2: Setup of the experiment hardware

chemical structure of the acriflavine dye. Table 1 shows the properties of the acriflavine dye. Eosin $\mathrm{Y}$ is also known as acid red 87 . It is a fluorescent red dye resulting from the action of bromine on fluorescent. Figure $1 \mathrm{~b}$ shows the chemical structure of the eosin Y dye. Table 1 shows the properties of the eosin $\mathrm{Y}$ dye.

LSC panels fabrication: In this study, the steps of constructing the LSC panels are demonstrated as follow: The primary dye concentration of each used dye was calculated using Eq. 1:

$$
\mathrm{C}=\frac{\mathrm{W} \times 1000}{\mathrm{M}_{\mathrm{W}} \times \mathrm{V}}
$$

Equation 1 was taken from (Dhabab, 2013) and rearranged. Where, $\mathrm{C}$ is the dye concentration $(\mathrm{mol} / \mathrm{L}) . \mathrm{W}$ is the weight of the dye $(\mathrm{g})$ measured using sensitive weighting balance. $M_{w}$ is the Molecular weight of the dye $(\mathrm{g} / \mathrm{moL}) . \mathrm{V}$ is the Volume of the solvent $(\mathrm{mL})$. The volume after dilution for each dye was calculated using Eq. 2:

$$
\mathrm{V}_{2}=\frac{\mathrm{C}_{1} \times \mathrm{V}_{1}}{\mathrm{C}^{2}}
$$

Equation 2 was taken from (Dhabab, 2013) and rearranged. Where $\mathrm{V}_{2}$ is the volume after dilution. $\mathrm{C}_{2}$ is the new concentration calculated from Eq. 1. $\mathrm{V}_{1}$ is the volume before dilution. $\mathrm{C}_{1}$ is the main required concentration. Four concentrations were used in this research which are $\left(2 \times 10^{-5}, 3 \times 10^{-5}, 6 \times 10^{-5}, 10 \times 10^{-5} \mathrm{~mol} / \mathrm{L}\right)$. The absorbance and fluorescence were measured for the acriflavine and $\operatorname{eosin} \mathrm{Y}$ dyes using UV-Visible spectrometer and spectrophotometer, respectively. These measurements were obtained also for the mixing of the two dyes. The volume after dilution $\left(\mathrm{V}_{2}\right)$ were taken from the acriflavine and eosin $\mathrm{Y}$ dyes and mixed with epoxy risen and hardener. The ratio of risen and hardener was (2:1).

The obtained mixture was placed in the panel casting mold of dimensions $\left(10 \times 10 \mathrm{~cm}^{2}\right)$ to fit the used solar cell dimensions and left for $48 \mathrm{~h}$ at room temperature.

Experiment: Figure 2 shows the setup of the system hardware. The distance between the solar cell and the light source (projector) was adjusted and fixed. The solar cell analyzer was used to measure the voltage, current, fill factor and solar cell efficiency. These measurements can be obtained from a computer connected to the solar cell analyzer. Also, a current-voltage curve can be obtained.

\section{RESULTS AND DISCUSSION}

Figure 3 shows the absorbance and fluorescence spectra of four concentrations $\left(2 \times 10^{-5}, 3 \times 10^{-5}, 6 \times 10^{-5}, 10 \times 10^{-5}\right.$ $\mathrm{mol} / \mathrm{L}$ ) of two dyes (acriflavine, eosin $\mathrm{Y}$ ) mixed with equal proportions. As can be seen, the two mixed dyes (acriflavine and eosin $\mathrm{Y}$ ) have high absorbance spectrum range (from $464-516 \mathrm{~nm}$ ). The peak of the absorbance spectrum is $464 \mathrm{~nm}$ at the concentration $2 \times 10^{-5}$ while the peak of the absorbance spectrum is $516 \mathrm{~nm}$ at the concentration $10 \times 10^{-5}$. The range of the fluorescence spectrum is from 588-561 nm. The peak of the fluorescence spectrum is $588 \mathrm{~nm}$ at the concentration $2^{*} 10^{-5}$ while the peak of the fluorescence spectrum is $561 \mathrm{~nm}$ at the concentration $10^{*} 10^{-5}$. Stokes shift $(\Delta \lambda)$ has been determined for the four concentrations of the mixed dyes. Stokes shift is the difference between the wavelengths of maximum fluorescence and absorbance (Table 2). MATLAB Software has been used to calculate the area under the curves of absorbance and fluorescence spectra (Fig. 3). These calculations have been used to calculate the quantum efficiency ( $\phi \mathrm{fm}$ ) which is the ratio between the area under the Fluorescence spectrum 
Table 2: Wavelength of maximum absorbance and flourescence, stokes shift, radiated and flourscence life time and quantam efficiency of four concentrations of two mixed dyes (acriflavine, eosin $\mathrm{Y}$ )

\begin{tabular}{lcccccc}
\hline $\begin{array}{l}\text { Concenttration } \\
(\mathrm{mol} / \mathrm{L})\end{array}$ & $\begin{array}{c}\text { Wavelength of max } \\
\text { absorbance } \lambda_{\text {abs }}(\mathrm{nm})\end{array}$ & $\begin{array}{c}\text { Wavelength of max } \\
\text { flourescence } \lambda_{\text {flo }}(\mathrm{nm})\end{array}$ & $\begin{array}{l}\text { Stokes shift } \\
\Delta \lambda_{\max } \lambda_{\text {flo }} \lambda_{\text {abs }}\end{array}$ & $\begin{array}{l}\text { Radiated life time } \\
\tau_{\text {fn }}(\mathrm{nsec})\end{array}$ & $\begin{array}{l}\text { Flourescence life } \\
\text { time } \tau_{\mathrm{f}}(\mathrm{nsec})\end{array}$ & $\begin{array}{c}\text { Quantumefficiency } \\
\phi_{\text {fn }}(\%)\end{array}$ \\
\hline $2 \times 10^{-5}$ & 464 & 488 & 24 & 2.489660 & 2.457046 & 98.6921 \\
$3 \times 10^{-5}$ & 530 & 555 & 25 & 5.210243 & 4.977867 & 95.5409 \\
$6 \times 10^{-5}$ & 515 & 558 & 43 & 6.210814 & 3.494204 & 56.2604 \\
$10 \times 10^{-5}$ & 516 & 561 & 45 & 9.164273 & 4.732431 & 51.6452 \\
\hline
\end{tabular}

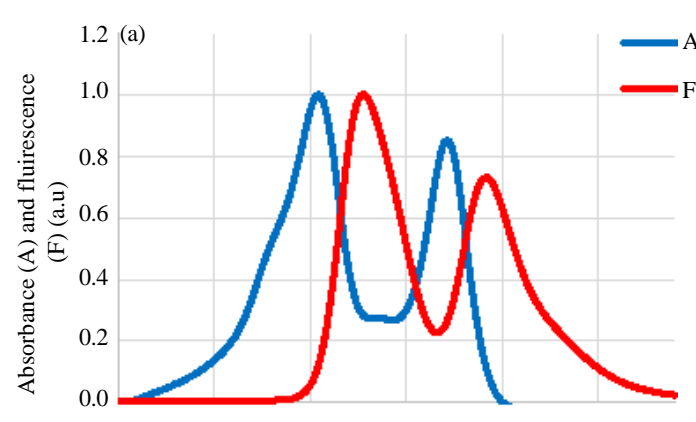

(c)

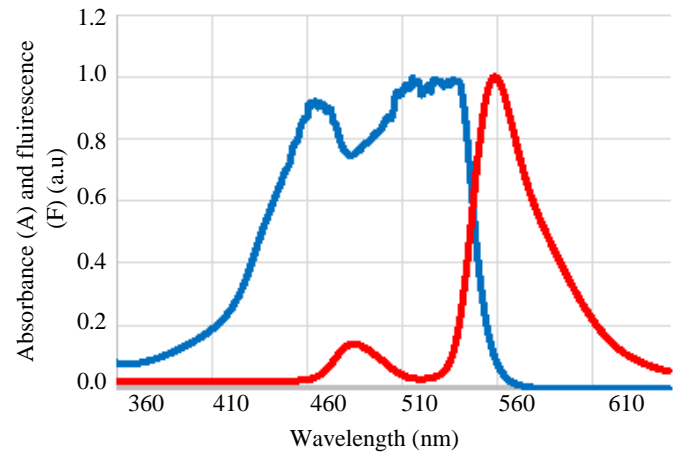

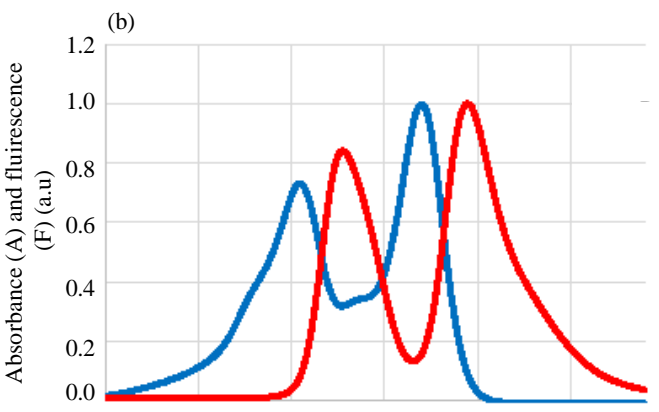

(d)

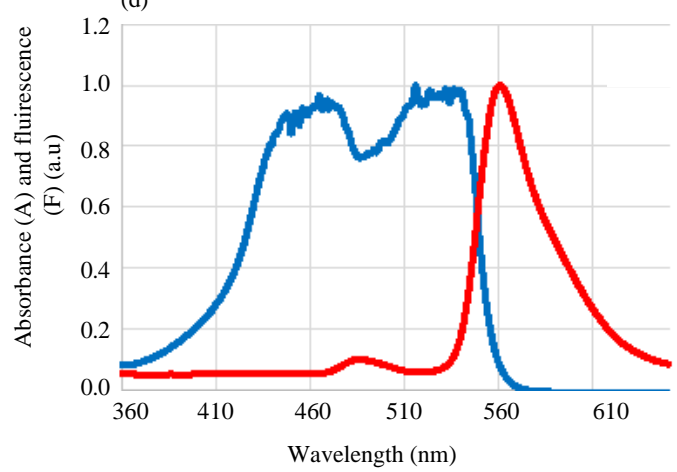

Fig. 3: The absorbance and flourescene spectra of four concentration of two mixed dyes (acriflavine, eosin Y; a) $\left.2 * 10^{-5} \mathrm{~mol} / \mathrm{L} ; \mathrm{b}\right) 3^{*} 10^{-5} ; \mathrm{c}^{*} 10-5 \mathrm{~mol} / \mathrm{L}$ and d) $10^{*} 10^{-5} \mathrm{~mol} / \mathrm{L}$

curve to the area under the absorbance spectrum curve (Table 1). Radiated lift time $\left(\tau_{\mathrm{fm}}\right)$ and fluorescence life time $\left(\tau_{f}\right)$ have been determined using the following Eq. 3 and 4:

$$
\begin{gathered}
\tau_{\mathrm{fm}}=\frac{1}{\mathrm{~K}_{\mathrm{fm}}} \\
\tau_{\mathrm{f}}=\mathrm{Q}_{\mathrm{fm}} \times \tau_{\mathrm{fm}}
\end{gathered}
$$

Where $\mathrm{K}_{\mathrm{fm}}$ is the rate of disappearance which can be calculated using the Einstein coefficient for self-emission equation (Ulrich et al., 2008).

Figure 4 s hows the current-voltage curves of the solar cell with the constructed LSC panels of the mixed dyes (acriflavine, eosin Y) with four concentrations with panel thickness 1 and $0.5 \mathrm{~mm}$. Table 3 shows the measurements of maximum current, maximum voltage, fill factor, solar cell efficiency with the use of LSC panels and the change ratio in the efficiency after the use of LSC panels.
Table 3 shows measurements of maximum current different rates depending on the dye concentration and panel $\left(\mathrm{I}_{\max }\right)$, maximum Voltage $\left(\mathrm{V}_{\max }\right)$, Fill Factor $(\mathrm{FF})$, solar cell thickness. the greatest increase in the efficiency of solar cell efficiency $(\eta)$ with the use of LSC panels and the change is $(9.922 \%)$ at the dyes concentration $\left(2 \times 10^{-5} \mathrm{~mol} / \mathrm{L}\right)$ and ratio in the efficiency $(\eta)$ after the use of LSC panels panel thickness $(1 \mathrm{~mm})$. However, the lowest efficiency of These measurements have been conducted using solar solar cell is $(9.080 \%)$ at the dyes concertation $\left(10 \times 10^{-5} \mathrm{~mol} / \mathrm{L}\right)$ module analyzer instrument which is connected to a and panel thickness $(0.5 \mathrm{~mm})$. The efficiency of solar cell is computer. The first raw in Table 2 shows the measurement increased at the panel thickness $(1 \mathrm{~mm})$ more than that at the of the pure solar cell without using any LSC panel. After the panel thickness $(0.5 \mathrm{~mm})$ for the same concentration. The use of different LSC panels, measurements have been reason for this is that the increment in the panel thickness conducted and compared with the firstraw measurement to leads to increase the dye molecules in the LSC 


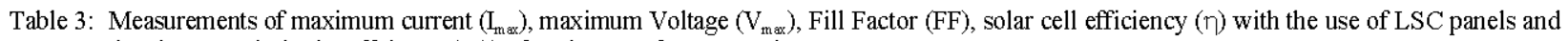
the change ratio in the effciency $(\eta \Delta)$ after the use of LSC panels

\begin{tabular}{lcccccc}
\hline Concentration $(\mathrm{mol} / \mathrm{L})$ & Thickness $(\mathrm{mm})$ & $\mathrm{I}_{\max }(\mathrm{mA})$ & $\mathrm{V}_{\max }(\mathrm{V})$ & $\mathrm{FF}$ & $\eta(\%)$ & $\eta \Delta(\%)$ \\
\hline Pure cell & -- & 59.50 & 4.126 & 0.720 & 8.183 & -- \\
$2 \times 10^{-5}$ & 1 & 73.70 & 4.039 & 0.790 & 9.922 & 21.25 \\
& 0.5 & 69.20 & 4.247 & 0.724 & 9.796 & 19.17 \\
$3 \times 10^{-5}$ & 1 & 71.10 & 4.144 & 0.792 & 9.821 & 20.01 \\
& 0.5 & 73.10 & 4.144 & 0.792 & 9.821 & 20.01 \\
$6 \times 10^{-5}$ & 1 & 66.80 & 4.199 & 0.758 & 9.449 & 14.24 \\
& 0.5 & 65.70 & 4.205 & 0.772 & 9.208 & 12.52 \\
$10 \times 10^{-5}$ & 1 & 66.20 & 4.137 & 0.830 & 9.128 & 1.54 \\
& 0.5 & 66.99 & 4.072 & 0.780 & 9.080 & 10.96 \\
\hline
\end{tabular}

(a)
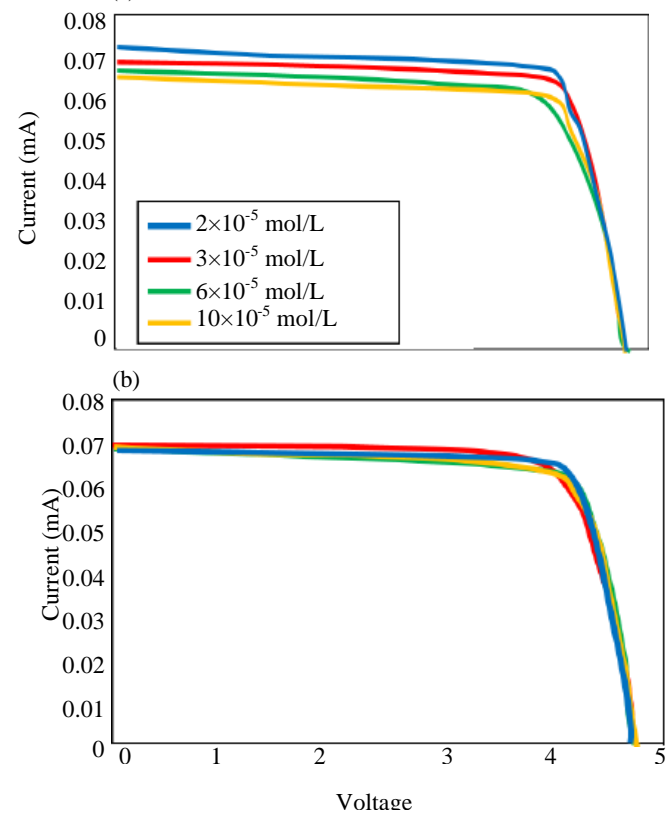

Fig. 4: Current-voltage curves of the solar cell with the constructed LSC panels of the mixed dyes (acriflavine, eosin Y) with four concentration; a) 1 $\mathrm{mm}$ panel thickness and b) $0.5 \mathrm{~mm}$ panel thickness

panel for limit obtain the increasing ratio $(\eta)$ in solar cell efficiency as range. Therefore, the fluorescence intensity can be increased shown in the following equation (Daram et al., 2011):

$$
\Delta \eta=\frac{\eta(\text { LSC })-\eta(\text { pure })}{\eta(\text { pure })} \times 100 \%
$$

As can be seen in Table 3 and Fig. 4, the greatest increase in the efficiency of solar cell is $(9.922 \%)$ at the dyes concentration $\left(2 \times 10^{-5} \mathrm{~mol} / \mathrm{L}\right)$ and panel thickness (1 $\mathrm{mm})$. However, the lowest efficiency of solar cell is $(9.080 \%)$ at the dyes concertation $(10 \times 10-5 \mathrm{~mol} / \mathrm{L})$ and panel thickness $(0.5 \mathrm{~mm})$.

It is important to mention that the efficiency of solar cell is increased at the panel thickness $(1 \mathrm{~mm})$ more than that at the panel thickness $(0.5 \mathrm{~mm})$ for the same concentration. The reason for this is that the increment in the panel thickness leads to increase the dye molecules in the LSC panel for limit range. Therefore, the fluorescence intensity can be increased as a result.

Another important point is that the solar cell efficiency with the LSC panels of lower dye concentrations is more than that with the use of LSC panels of higher dye concentrations. The reason of this is that at the low concentrations, the number of probable collisions between dye molecules is decreased. However, at the higher concentrations, the likelihood of molecules collisions is increased. Therefore, the increase in the collisions number leads to increasing the heat of LSC panel which affects the fluorescence process accordingly.

\section{CONCLUSION}

Different dye concentrations and different LSC panel thicknesses have been used and tested to determine the best concentration and panel thickness which helped to increase the conversion efficiency of the solar cell. From the obtained results, it was found that all the LSC panels of the mixed dyes (Acriflavine and Eosin Y) have increased the conversion efficiency of the solar cell by different rates depending on the dye concentration and panel thickness. The greatest increase in the efficiency of solar cell is $(9.922 \%)$ at the dyes concentration $(2 \times 10-5 \mathrm{~mol} / \mathrm{L})$ and panel thickness $(1 \mathrm{~mm})$. However, the lowest efficiency of solar cell is $(9.080 \%)$ at the dyes concertation $\left(10^{*} 10^{-5}\right.$ $\mathrm{Mol} / \mathrm{L})$ and panel thickness $(0.5 \mathrm{~mm})$. The efficiency of solar cell is increased at the panel thickness $(1 \mathrm{~mm})$ more than that at the panel thickness $(0.5 \mathrm{~mm})$ for the same concentration. The reas on for this is that the incrment in the panel thickness leads to increase the dye molecules in the LSC panel for limit range. Therefore, the fluorescence intensity can be increased as a result. In addition, the solar cell efficiency with the LSC panels of lower dye concentrations is more than that with the use of LSC panels of higher dye concentrations. The reas on of this is that at the low concentrations, the number of probable collisions between dye molecules is decreased. However, at the higher concentrations, the likelihood of molecules collisions is increased. Therefore, the increase in the collisions number leads to increasing the heat of LSC panel which affects the fluorescence process accordingly. 


\section{RECOMMENDATIONS}

Future research can be done by testing different concentrations and different panel thicknesses to evaluate the best range of dye concentrations and panel thicknesses. part of the proposed algorithm was tested using six data sets. The data sets contain different times and weather conditions. The vehicle counting algorithm is compared with the manual counting which is considered as ground truth. The experiments show a good result as $(90.8 \%)$ for vehicle counting. To evaluate the proposed vehicle speed measurement algorithm, we used five videos from five datasets available online where these data sets have a ground truth file for the actual speed of each vehicle using very precise inductive loop detector. Experiments shows that the speeds measurements were within the acceptable error interval where the speed measurement was considered acceptable if it is within the $[-5$, and $+5 \mathrm{~km} / \mathrm{h}]$.

\section{ACKNOWLEDGEMENT}

This research is supported by the Department of Physics, Faculty of Science, University of Kufa.

\section{REFERENCES}

Anonymus, 2018a. Login to weatherSTEM scholar. WeatherSTEM, Tallahassee, Florida. https://www. weatherstem.com/login?redirect $=$ https: $/ /$ learn. weathe rstem.com/modules/learn/lessons/1/09.html\&mode= Scholar

Anonymus, 2018b. Renewable energy. STELR Project, Australia. https: //stelr .org. au/stelr-modules/ renewable-energy/\#additional-info

Armaroli, N. and V. Balzani, 2007. The future of energy supply: Challenges and opportunities. Angew. Chem. Intl. Edn., 46: 52-66.

Daram, B., K.R. Al-Rawi and S.A. Hussin, 2011. Improve the performance efficiency of solar cell by using epoxy plates doped with rhodamine 6G dye. Indian J. Sci. Technol., 4: 1726-1731.
Dhabab, J.M., 2013. Methods and modern techniques in instrumental chemical analysis. Master Thesis, Department of Chemistry, College of Science, Al-Mustansyriah University, Baghdad, Iraq.

Dhakal, T.P., 2016. Getting more energy from the sun: How to make better solar cells. The Conversation Media Group Ltd, ?Melbourne, Australia.

Ladoulis, C.T. and T.J. Gill, 1970. Physical chemical studies on the specific interaction of an acriflavine-phosphotungstic acid complex with double-stranded nucleic acids. J. Cell Bio., 47: 500-511.

Li, R., S. Wang, S. Chuwongin and W. Zhou, 2013. Nanoscale silver-assisted wet etching of crystalline silicon for anti-reflection surface textures. J. Nanosci. Nanotechnol., 13: 493-497.

Lin, X.X., Y. Zeng, S.H. Zhong, Z.G. Huang and H.Q. Qian et al., 2015. Realization of improved efficiency on nanostructured multicrystalline silicon solar cells for mass production. Nanotechnol., 26: 1-11.

Mohamed, A.M. and A.F. Hassan, 2015. Improve solar cell energy conversion efficiency by using illuminescent dyes concentrators. J. Kufa Phys., 7: 8-15.

Reisfeld, R., 1983. Future technological applications of rare-earth-doped materials. J. Less Common Met., 93: 243-251.

Rowan, B.C., L.R. Wilson and B.S. Richards, 2008. Advanced material concepts for luminescent solar concentrators. IEEE J. Selected Top. Quantum Electron., 14: 1312-1322.

Truant, J.P., W.A. Brett and J.W. Thomas, 1962. Fluorescence microscopy of tubercle bacilli stained with auramine and rhodamine. Henry Ford Hosp. Med. Bull., 10: 287-296.

Ulrich, G., R. Ziessel and A. Harriman, 2008. The chemistry of fluorescent bodipy dyes: Versatility unsurpassed. Angew. Chem. Intl. Edn., 47: 1184-1201.

Van Sark, W.G., K.W. Barnham, L.H. Slooff, A.J. Chatten and A. Buchtemann et al., 2008. Luminescent solar concentrators-A review of recent results. Opt. Exp., 16: 21773-21792. 